\title{
Does migraine headache affect cognitive function in the elderly? Report from the Maastricht Aging Study (MAAS).
}

Citation for published version (APA):

Jelicic, M., van Boxtel, M. P. J., Houx, P. J., \& Jolles, J. (2000). Does migraine headache affect cognitive function in the elderly? Report from the Maastricht Aging Study (MAAS). Headache: The Journal of Head and Face Pain, 40, 40-40. https://doi.org/10.1046/j.1526-4610.2000.00124.x

Document status and date:

Published: 01/01/2000

DOI:

10.1046/j.1526-4610.2000.00124.x

Document Version:

Publisher's PDF, also known as Version of record

Please check the document version of this publication:

- A submitted manuscript is the version of the article upon submission and before peer-review. There can be important differences between the submitted version and the official published version of record.

People interested in the research are advised to contact the author for the final version of the publication, or visit the DOI to the publisher's website.

- The final author version and the galley proof are versions of the publication after peer review.

- The final published version features the final layout of the paper including the volume, issue and page numbers.

Link to publication

\footnotetext{
General rights rights.

- You may freely distribute the URL identifying the publication in the public portal. please follow below link for the End User Agreement:

www.umlib.nl/taverne-license

Take down policy

If you believe that this document breaches copyright please contact us at:

repository@maastrichtuniversity.nl

providing details and we will investigate your claim.
}

Copyright and moral rights for the publications made accessible in the public portal are retained by the authors and/or other copyright owners and it is a condition of accessing publications that users recognise and abide by the legal requirements associated with these

- Users may download and print one copy of any publication from the public portal for the purpose of private study or research.

- You may not further distribute the material or use it for any profit-making activity or commercial gain

If the publication is distributed under the terms of Article 25fa of the Dutch Copyright Act, indicated by the "Taverne" license above, 


\title{
Does Migraine Headache Affect Cognitive Function in the Elderly? Report From the Maastricht Aging Study (MAAS)
}

\author{
Marko Jelicic, PhD; Martin P.J. van Boxtel, MD, PhD; Peter J. Houx, PhD; Jelle Jolles, PhD
}

\begin{abstract}
The aim of this study was to examine two aspects of cognitive functioning-information processing speed and memory -in both young/middle-aged and older subjects with and without migraine, using data from a large population-based sample. We found that, although age had a large effect on processing speed and memory, migraine did not influence cognitive performance. In addition, there was no significant interaction between age and migraine on processing speed and memory. Our results suggest that, in the general population, migraine does not seriously affect cognitive functioning in young/middle-aged or older adults.
\end{abstract}

Key words: migraine, old age, cognitive function

Abbreviations: BRC brain reserve capacity, MAAS Maastricht Aging Study, LDST Letter Digit Substitution Test, VLT Verbal Learning Test, DR delay recall

(Headache 2000;40:715-719)

There is controversy as to whether migraine affects cognitive function. In some studies, it was found that patients with migraine had lower performance on cognitive tasks than matched control subjects, ${ }^{1-3}$ suggesting that migraine may lead to central nervous system dysfunction. Conversely, other investigations failed to find an association between migraine and cognitive performance, ${ }^{4-6}$ suggesting that migraine is a rather benign syndrome not causing any brain injury. Leijdekkers and colleagues ${ }^{5}$ argued that sample differences may account for these discrepant findings. Selected patient samples were used in studies showing a relationship between migraine and cognition. The patient groups in those investigations consisted

From the Department of Psychiatry and Neuropsychology, Neuropsychology and Biopsychology Section, Maastricht Brain and Behavior Institute and European Graduate School of Neuroscience (EURON), Maastricht University, The Netheriands.

Address all correspondence to Dr. M. Jelicic, Department of Psychiatry and Neuropsychology, Neuropsychology and Biopsychology Section, Maastricht University, P.o. Box 616, 6200 MD Maastricht, The Netherlands.

Accepted for publication June 8, 2000. mainly of people with severe migraine requiring prolonged medical treatment. Studies in which no effect of migraine on cognitive performance was found generally used migraineurs recruited from the general population (often people with mild or moderate forms of migraine). Leijdekkers and colleagues therefore concluded that only severe migraine affects the central nervous system resulting in cognitive impairments.

Virtually all studies on migraine and cognitive function were conducted in young or middle-aged subjects. However, there is reason to believe that migraine has a larger impact on cognitive function in the elderly than in young adults. Satz recently reformulated the concept of "brain reserve capacity" (BRC). ${ }^{7}$ He pointed out that brain injury does not necessarily lead to cognitive deficits: a substantial number of neurons must be damaged (beyond a certain threshold) before impairments will emerge. Magnetic resonance imaging (MRI) research has demonstrated that old age is associated with a loss of neurons in brain areas responsible for information processing and memory, ${ }^{8}$ indicating less BRC in older adults than in young people. Therefore, it is conceivable that, in the general population, subtle brain injury brought about 
by migraine will not influence young people's cognitive performance, but may reduce cognitive function in the elderly. In young people, neuronal loss due to migraine would not pass the threshold for the emergence of cognitive deficits, whereas in older people, because of their lowered BRC, it would. This line of reasoning is supported by studies showing MRI abnormalities in older migraineurs ${ }^{9.10}$ (although this is not a ubiquitous finding ${ }^{11}$ ). The aim of the present study was to test the hypothesis that migraine leads to cognitive impairments in the elderly, using data from the Maastricht Aging Study (MAAS). This is a large, longitudinal, population-based study conducted in The Netherlands, involving almost 2000 healthy subjects aged 25 to 80 years.

\section{SUBJECTS AND METHODS}

The MAAS is a population-based, longitudinal study on the determinants and consequences of cognitive aging. ${ }^{12}$ For this article, we used data from the first data wave of the MAAS (the baseline measurement).

Subjects.-Subjects participating in the baseline of the MAAS were randomly drawn from a register of family physicians affiliated with the University of Maastricht. ${ }^{13}$ The register contains all relevant past and current medical morbidity of the patients. Subjects were not included in the MAAS if they had known brain-related disorders. Other exclusion criteria were cerebrovascular disease, mental retardation, or psychotropic drug use. The sample consisted of 1869 patients, stratified for age (12 discontinuous age classes [ranging from $25 \pm 1$ years to $80 \pm 1$ years]), gender, and occupational achievement (in two levels) as an indicator of general ability. Stratification was necessary in order to control for the effect of these well-known predictors of cognitive performance in different age strata. More information on subject recruitment and stratification can be found elsewhere. ${ }^{12.14}$ Data from the register of family physicians made it possible to compare several important background characteristics (ie, age, gender, educational level, and general health status) of participants and nonparticipants in the MAAS. It was found that participation was only marginally affected by age, gender, and edu- cation. All subjects underwent an extensive medical and neuropsychological examination, which took about 3 hours to complete. Additional sociodemographic and health information was obtained by questionnaire. The data collection of the MAAS baseline started in 1993 and was completed in 1995.

Dependent Variables.-Researchers have made a distinction between basic processes of cognition (eg, information processing speed) and more complex products of cognition (eg, memory function) ${ }^{15}$ In our study, basic processes of cognition were assessed with the Letter Digit Substitution Test (LDST), a modification of the Symbol Digit Modalities Test. ${ }^{16}$ At the top of the page, subjects are presented with a code in which a digit corresponds to a letter, and are asked to fill in blanks using the correct digit/letter codes. The number of letters correctly written in 1 minute is a measure of speed of information processing. Memory, a complex product of cognition, was assessed with the Verbal Learning Test (VLT). ${ }^{17}$ Subjects are presented with 15 monosyllabic words on a computer screen at a rate of one word per 2 seconds. Next, they are asked to recall as many words from the list as possible (in any order). This procedure was repeated four times with the same stimulus words. Twenty minutes after the last trial, subjects were given a delayed recall (DR) task. They were again requested to recall words from the study list. We used the DR task of the VLT as a dependent variable. Neuropsychological research has shown that this task is a very sensitive memory measure. Patients with organic amnesia, eg, patients with Korsakoff syndrome, perform very poorly on the DR task of the VLT. ${ }^{18}$ Both the LDST and the VLT have acceptable psychometric characteristics, and reliability and validity of these two cognitive tests were found to be reasonable. ${ }^{19}$

Independent Variables.-Age and the presence of migraine were selected as independent variables. A checklist of chronic medical conditions was administered to all subjects. One of the conditions on the checklist was migraine. In order to reduce potential reporting bias by the subjects, we specifically asked whether or not migraine was currently a health problem. Because the majority of those with migraine do not visit a physician for their headache problems, ${ }^{20}$ 
Table 1.-Cognitive Test Scores of Subjects With and Without Migraine

\begin{tabular}{|c|c|c|c|c|}
\hline & \multicolumn{2}{|c|}{ With Migraine } & \multicolumn{2}{|c|}{ Without Migraine } \\
\hline & No. of Subjects & Mean \pm SD Score & No. of Subjects & Mean \pm SD Score \\
\hline LDST & 99 & $38.25 \pm 8.29$ & 1753 & $37.95 \pm 8.53$ \\
\hline DR (VLT) & 98 & $9.54 \pm 2.95$ & 1734 & $9.61 \pm 3.10$ \\
\hline
\end{tabular}

LDST indicates Letter Digit Substitution Test; DR (VLT), Delayed Recall from the Verbal Learning Test.

we did not select migraineurs from the family physicians' morbidity register.

Data Analysis.-Analysis of variance (ANOVA) was used to determine if age and migraine had an effect on the LDST and the DR task of the VLT. Given our hypothesis that migraine would affect cognitive performance in the elderly but not in younger adults, we also tested for an age $\times$ migraine interaction.

\section{RESULTS}

There were 99 subjects with migraine (mean age $\pm \mathrm{SD}, 52.0 \pm 14.6$ years) and 1768 without migraine (mean age $\pm S D, 52.0 \pm 16.7$ years). Sixty-five of the migraineurs were women. The mean \pm SD scores on the two measures of cognitive function for both groups are presented in Table 1. The scores of older adults from both groups (aged 64 years or older) are shown in Table 2. Analysis of variance demonstrated a significant main effect of age on both cognitive tests $(P<.001$ for both). No main effect of migraine on the two measures of cognition was found
$(P=.343$ for information processing speed; $P=.930$ for memory), nor were there age $\times$ migraine interactions $(P=.597$ for speed of processing; $P=.377$ for memory).

\section{COMMENTS}

We have demonstrated in a population-based sample that migraine was not associated with cognitive impairments. This finding is in accordance with previous research demonstrating that young and/or middle-aged migraineurs recruited from the general population were not outperformed by matched controls on cognitive tests. ${ }^{4-6}$ Also, we failed to find an age $\times$ migraine interaction on cognitive performance, suggesting that migraine does not cause accelerated cognitive aging. Although older people generally have less BRC and lower cognitive function than younger people, our findings show that migraine in the elderly does not lead to additional cognitive decline.

Cognitive functioning in old age is affected by medical conditions, especially lung disease and diabe-

Table 2.-Cognitive Test Scores of Older Subjects With and Without Migraine

\begin{tabular}{|c|c|c|c|c|}
\hline & \multicolumn{2}{|c|}{ With Migraine } & \multicolumn{2}{|c|}{ Without Migraine } \\
\hline & No. of Subjects & Mean \pm SD Score & No. of Subjects & Mean \pm SD Score \\
\hline LDST & 24 & $31.71 \pm 7.54$ & 546 & $31.80 \pm 7.04$ \\
\hline DR (VLT) & 23 & $7.09 \pm 3.01$ & 540 & $7.75 \pm 3.05$ \\
\hline
\end{tabular}

LDST indicates Letter Digit Substitution Test; DR (VLT), Delayed Recall from the Verbal Learning Test. 
tes. ${ }^{14.21}$ We may have failed to find an effect of migraine on cognition because there were more patients with these two medical conditions in the control group than in the migraine group. Therefore, we performed the same statistical analyses with all patients with lung disease and diabetes excluded. The results of these analyses did not differ from our initial results.

Our study has two limitations. First, subjects were given a list of medical conditions and asked to check whether or not they had migraine. Some MAAS participants with nonmigraine headache may have indicated they had migraine because they believed themselves to be suffering from migraine. As a result, our migraine group might have contained a few nonmigraineurs. However, this is not a likely scenario. The checklist was administered to all subjects while visiting the laboratory. Whenever a subject was not sure if he or she was suffering from a condition on the list, a research physician was consulted. Furthermore, the proportion of people with migraine in our sample was somewhat lower than the proportion of migraineurs found in a recent Dutch epidemiological study (in which the International Headache Society criteria for migraine were used). ${ }^{22}$ A second limitation concerns the MAAS exclusion criteria. Psychotropic drug users were excluded from the MAAS. Since migraine is occasionally associated with psychiatric disorders, ${ }^{23}$ some migraineurs may have been excluded from the MAAS because they used psychotropic drugs as a treatment for comorbid psychopathology. Similarly, people with brain-related and cardiovascular conditions were also not included in the MAAS. As a consequence, participants in the MAAS are somewhat healthier than people randomly drawn from the Dutch population. This raises the possibility that our migraine group may have consisted mainly of those with mild or moderate migraine. Cognitive impairment has been found in young and middle-aged patients who needed prolonged medical treatment for their migraine..$^{1-3}$ Therefore, elderly with severe forms of migraine could still show more cognitive loss than "normal" elderly.

Notwithstanding these limitations, we conclude that migraine does not consistently affect cognitive function in both young/middle-aged and older subjects in the general population.
Acknowledgments: This research was supported in part by a grant from the Dutch Ministeries of Education, Health, and Welfare, via the Steering Committee for Gerontological Research (NESTOR). It is part of the Maastricht Aging Study (MAAS).

\section{REFERENCES}

1. Zeitlin C, Oddy M. Cognitive impairment in patients with severe migraine. Br J Clin Psychol. 1984;23(pt 1):27-35.

2. Hooker WD, Raskin NH. Neuropsychologic alterations in classic and common migraine. Arch Neurol. 1986;43:709-712.

3. Ardila A, Sanchez E. Neuropsychologic symptoms in the migraine syndrome. Cephalalgia. 1988;8:67-70.

4. Burker E, Hannay HJ, Halsey JH. Neuropsychological functioning and personality characteristics of migrainous and nonmigrainous female college students. Neuropsychology. 1989;3:61-73.

5. Leijdekkers ML, Passchier J, Goudswaard P, Menges LJ, Orlebeke JF. Migraine patients cognitively impaired? Headache. 1990;30:352-358.

6. Bell BD, Primeau M, Sweet JJ, Lofland KR. Neuropsychological functioning in migraine headache, nonheadache chronic pain, and mild traumatic brain injury patients. Arch Clin Neuropsychol. 1999;14: 389-399.

7. Satz P. Brain reserve capacity on symptom onset after brain injury: a formulation and review of the evidence for threshold theory. Neuropsychology. 1993; 7:273-295.

8. Golomb J, de Leon MJ, Kluger A, George AE, Tarshish C, Ferris SH. Hippocampal atrophy in normal aging. An association with recent memory impairment. Arch Neurol. 1993;50:967-973.

9. Ziegler DK, Batnitzky S, Barter R, McMillan JH. Magnetic resonance image abnormality in migraine with aura. Cephalalgia. 1991;11:147-150.

10. Robbins L, Friedman H. MRI in migraineurs. Headache. 1992;32:507-508.

11. Cooney BS, Grossman RI, Farber RE, Goin JE, Galetta SL. Frequency of magnetic resonance imaging abnormalities in patients with migraine. Headache. 1996;36:616-621.

12. Jolles J, Houx PJ, van Boxtel MP, Ponds RW. The Maastricht Aging Study. Determinants of Cognitive Aging, Maastricht: Neuropsych Publishers; 1995.

13. Metsemakers JF, Hoppener P, Knottnerus JA, 
Kocken RJ, Limonard CB. Computerized health information in the Netherlands: a registration network of family practices. BrJ Gen Pract. 1992;42:102-106.

14. van Boxtel MP, Buntinx F, Houx PJ, Metsemakers JF, Knottnerus JA, Jolles J. The relation between morbidity and cognitive performance in a normal aging population. J Gerontol. 1998;53A:M147-M154.

15. Salthouse TA. Cognitive and information-processing perspectives on aging. In: Nordhus IH, VandenBos GR, Berg S, Fromholt P, eds. Clinical Geropsychology. Washington, DC: American Psychological Association; 1998:49-59.

16. Smith A. The Symbol Digit Modalities Test: a neuropsychological test for economic screening of learning and other cerebral disorders. Learn Dis. 1968;36:83-91.

17. Brand N, Jolles J. Learning and retrieval rate of words presented auditorily and visually. J Gen Psychol. 1985;112:201-210.
18. Parkin AJ, Leng NR. Neuropsychology of the Amnesic Syndrome. Hove: Lawrence Erlbaum Associates; 1993.

19. Lezak MD. Neuropsychological Assessment. 3rd ed. New York, NY: Oxford University Press; 1995.

20. Silberstein SD, Lipton RB. Epidemiology of migraine. Neuroepidemiology. 1993;12:179-194.

21. Jelicic M, Kempen GI. Cognitive function in community-dwelling elderly with chronic medical conditions. Int J Geriatr Psychiatry. 1997;12:1039-1041.

22. Launer LJ, Terwindt GM, Ferrari MD. The prevalence and characteristics of migraine in a populationbased cohort: the GEM study. Neurology. 1999;53: 537-542.

23. Keck PE Jr, Merikangas KR, McEIroy SL, Strakowski SM. Diagnostic and treatment implications of psychiatric comorbidity with migraine. Ann Clin Psychiatry. 1994;6:165-171. 